\title{
Scriptural ethical principles and traditional African ethics
}

\author{
J.A. van Rooy \\ Dept. Old \& New Testament \\ Potchefstroom University for CHE \\ POTCHEFSTROOM
}

\begin{abstract}
Scriptural ethical principles and traditional African ethics

The traditional ethical code of Africa is dominated by two factors, to wit, interpersonal relationships, which include the ancestor spirits, and taboo, which is mainly concerned with respecting the hierarchy of forces. God is hardly a factor in everyday conduct. Biblical ethics, on the other hand, is totally dominated by the idea of and relationship with God. The origin of biblical ethics (creation and redemption), history (God's redemptive acts), content (being God's image, holy as He is holy), motivation (do as I have done to you), responsibility (both individual and communal responsibility) is directed towards God. Expectation (rewards and sanctions), universality (including all peoples, since God is the Creator of all), internal character (in that thoughts and motives are also judged by God), teaching about property, jurisprudence (placing kings and the lowliest on the same level before Gad and his law), and work ethic (which is strongly critical of using any magical means) - all of these are God-centred, and therefore sharply distingwished from African ethics which is man-centred. In the New Testament, the distingwishing factor is the new being, who is in Christ, being born again by the Holy Spirit, by which man is conformed to the image of his Redeemer and King. The dominant theme in both Testaments is love, which in African ethics is reserved for one's nearest kin, but in Scripture demanded even for one 's enemies.
\end{abstract}

\section{Introduction}

For more than one reason, Old Testament ethics is, despite its limitations (Vriezen, 1974:430-437), of paramount importance for New Testament Christians. In the first place, the New Testament did not replace Old Testament ethics with a new code of ethics, but presupposed it and built on it, bringing to it the new dimension of salvation in Christ Jesus and the endowment with the power of the Spirit. That is the reason why very few economic, political and social principles were spelt out by the New Testament: they had already been spelt out in the Old Testament. Secondly, New Testament Christians lived as a suppressed minority in a vast pagan empire. The ethical instructions given to them were not in the first place intended for a society in which believers had any influence in the government of a country. Like Abraham, they knew that they 
were aliens and strangers on earth (Heb. 11:13), and that their citizenship was in heaven (Phil. 3:20). As a result their ethics tended to reflect the character of being meant for aliens on this earth, who by their conduct testify to their heavenly Lord and his kingdom. For instructions about social, economical and political ethics, and for the rich revelation of God about Christian ethics to be found there, one has first of all to turn to the Old Testament with its theocratical set-up. The contribution of the New Testament to Christian ethics is to be found mainly in the work of the Holy Spirit, who enables and motivates God's people to conform to the image of Christ their Lord.

In order to forestall misunderstanding, it is necessary to take into account that this article is not a comparison between African and Western European ethics. The author does not regard traditional European or even Israelite ethics as superior to traditional African ethics. The influence of modern European ethics, with its disregard for the value of the community and for parental authority, is to be regarded as a negative rather than a positive factor. The fact that European and Israelite ethics are not critisized in this article, does not point towards any admiration for those, but merely means that they fall beyond the scope of this article.

\section{African ethics: interpersonal relationships and taboo}

In Africa the ethical code is determined mainly by two factors, namely interpersonal relationships and taboo (McVeigh, 1974:21, 84, 85, 91), which are interrelated and interdependent. Taboo refers in the first place to one's attitude towards the hierarchy of forces into which one is supposed to be integrated, but there are also quite a number of taboos which rule interpersonal relations, not least because those relations are regulated inter alia by laws of seniority. God, and man's relationship with him, is, generally speaking, not a factor of any significance in African ethics. We therefore have to disagree with Vriezen (1974:408) when he writes: "In all religions the relation between man and man is fundamentally determined by the relation between God and man. Always and everywhere religion and ethics are bound more or less closely together."

In Africa, the absence of any influence on the ethics of the relationship between God and man is very conspicious among most peoples. True, Modimo may be the energy vivifying man and his community, and therefore may be regarded as the "guardian" of ethical norms, but there is no revealed will of Modimo about these norms, neither are they observed out of love and respect for IT. It does not call men to account for their behaviour. There is consequently no essential difference between "ethical" norms and the cosmic order. 


\subsection{The hierarchy of forces and taboo}

Considering how important the principle of the hierarchy of forces is in African Traditional Religion, one should not be surprised that this is a factor determining norms of human conduct. It is an essential and basic principle of African ethics to respect this hierarchy of forces, to know and accept one's place in this totality and in society - a basic principle implying observing the taboos of the tribe and respecting the authority of one's seniors and preserving the wholeness and welfare of the community (Metuh, 1981:108). In African ethics there is an elaborate code of rules for conduct (McVeigh, 1974:84, 85, 91), designed to protect the hierarchy of forces against would-be transgressors. A younger brother should not marry first; a wife should not throw her husband on the ground when they quarrel (Ilogu, 1974:125); a totem animal should never be eaten.

The important point is that this code of norms is not related to any personal communion with God, and therefore has a strongly legalistic character. "It is not done," "It is taboo," is sufficient motivation for declaring an action forbidden (Ilogu, 1974:137). Tradition is sufficient authority. For the same reason this code of norms is strongly negative, concerned with what is forbidden rather than with positive behaviour (Setiloane, 1976:32)

A serious social problem with such a legalistic moral code is that it could function fairly well in a protective traditional society, but totally breaks down in the bewildering variety of life and range of choices in modern urban society (Rader, 1991:146). There is a need for a biblical basis for ethics in modern Africa, especially among Christians, who often have not yet integrated their faith into a comprehensive world view.

\subsection{Human relations}

In Africa, human relationships is a matter of primary importance - a matter which determines ethical norms, modes of conduct and principles of education. This means that ultimately man is thrown back upon himself and his society in establishing ethical norms of conduct. Man has no personal knowledge of God and his law which expresses his will, and consequently the ethical code has become entirely man-centred. There are very few instances recorded where God is concerned with human behaviour towards other persons (Mbiti 1975:31; Metuh, 1981:108, 109, 115, 116).

When we say that African ethics has a man-centred motivation, the issue of ancestor spirits is included in the human community, since the ancestor spirits are regarded as part of the extended family (Smith, 1950:87).

It seems, therefore, that in cases where God is thought to be interested in human ethics at all, his interest is limited to the maintenance of cosmic order, of which 
respect for seniority among members of the family is one aspect. In this way God may be indirectly involved in interpersonal ethics, but usually He does not determine what is right or wrong in one's conduct (Dymond in Smith ed. 1950:144, 149, 150; Davidson, 1950:178; Rosemary Guillebaud in Smith ed. 1950:199; Mbiti, 1970:248-249, 251).

The communal character of moral principles is reflected in the ethical code and education of African people. Characteristics which are inculcated in children in traditional education are those which would facilitate human relationships and prevent disunity in the community, such as respect for authority and seniority, humility, modesty, politeness, friendliness, willingness to compromise, sharing with others what one acquires, helping people in need, hospitality (see also Setiloane, 1976:67). It is remarkable how many of these characteristics are recommended in the book of Proverbs. Many African proverbs actually express the same wisdom as found in Proverbs. These African proverbs are remarkable and worth following, but this list unfortunately includes characteristics such as flattery, especially of important persons, telling persons what one suspects they would like to hear instead of telling them the truth; jealousy of persons who are more prosperous than oneself - norms which stand in direct opposition to a biblical moral code. This code of conduct also excludes many traits of character which biblical faith demands of believers, such as the fear of the Lord, dependability, integrity, diligence in one's work and especially love for strangers. Biblical ethics would provide a much sounder basis for reconciliation in a strifetorn society such as is presently being experienced in South Africa.

\section{Biblical ethics}

Although the Old Testament offers traces of a precovenantal set of moral values, as expressed by the sayings "This is not done in Israel" and "a disgrace in Israel" (Gen. 34:7; Jos. 7:15; Jgd. 19:23f., 30; 20:6, 10; 2 Sam. 13:12; Jer. 29:23 and Eichrodt, 1967:317), or manifested by Judah in his relations to Tamar (Gen. 38), or of the sons of Jacob in their dealings with the Shechemites (Gen. 34:25), this does not mean that the theocratic motivation was entirely absent. The implications of the election of Abraham and his descendants was not entirely lost on all of the patriarchs. A clear indication that it actually was a factor to be taken into account is found in the history of Joseph, as for example in his reply to the advances of the wife of Potiphar (Gen. 39:9) or in his reassurance to his brothers: "I fear God" (Gen. 42:18f.). Even the negative statement of Abraham to Abimelech in Genesis 20:11, "I said to myself, "There is surely no fear of God in this place"", indicates that ideally the fear of God was supposed to direct men in their conduct towards their fellow-men - at least according to Abraham.

However, when God established his covenant with Israel and revealed his will to them in his law, a new dimension was introduced into the motivation for human 
conduct. Since then, human conduct has been primarily a religious matter (Snaith, 1944:59). What was regarded as good rested on the recognition of God as the One who is perfectly good (Eichrodt, 1967:316). Kaiser $(1983: 5,3)$ calls Old Testament ethics in the first place theistic. "It is Israel's depiction of God that sets it off from most other ethical systems". To what extent the religious obligations of the Covenant dominated interpersonal relationships is illustrated inter alia by the fact that faithfulness towards other persons, even when against one's own interests, is called by Jonathan "loyal love such as God requires" (1 Sam. 20:14, cf. Eichrodt, 1967:322; De Groot \& Hulst, 1952:281).

The fact that Yahweh is a personal God, also profoundly influences the ethical code of the Old Testament. Whatever changes in accent and in nuance there may have occurred in the course of the history of Israel, this one factor remained constant in the faith of believing Israel: ethics is founded on the expressed personal will of a personal God, who has revealed that will to his people in the covenant legislation (Kaiser, 1983:5, 20; Dyrness, 1979:172; Vriezen, 1974: 412). Leviticus 19:18 lays down the precept, "Love your neighbour as yourself", immediately followed by the motivation, "I am the LORD", and the same applies to Leviticus 19:33, 34, where the Israelite is told to treat the alien with kindness, "Love him as yourself. I am the LORD your God". This commandment is, therefore, not a mere social prescription, but is rooted in Israel's faith in God (Vriezen, 1974:416). The relationship between man and man is determined by that between man and God (Vriezen, 1974:420). In the Old Testament morality is an integral part of religion. God is the source of the good, and if man is to do good, that is because he knows God (Dymess, 1979:172).

Not only the fact that God was regarded as the living God, a God who lived in personal fellowship with his Covenant people, influenced the ethical code of Israel, but also the fact that $\mathrm{He}$ was regarded as the one and only God. Polytheism involves a variety of standards, which in the end boils down to no standard at all (Vriezen, 1974:411; Dymess, 1979:173). Yahweh's will was clearly and absolutely one, and in that respect there was a vast difference between Old Testament ethics and ancient Semitic ethics. James 2:10-11 is based squarely on Old Testament principles: "He who said, 'Do not commit adultery', also said, 'Do not murder". Biblical ethics is consistent and unchanging, because God is consistent and unchanging (1 Sam. 15:29; Ps. 25:8$10)$.

\subsection{God-centred origin}

The God-centred origin of Israel's ethics is to be found both in creation (Kaiser, 1983:31; Dymess, 1979:75), and in the covenant (Wright, 1983:21). The ethical stipulations of the covenant are made on the basis and in the light of God's work of creation and redemption. The theological basis for ethical matters such as 
marriage, human sexuality, duties to parents, duties to employees, property, work, life and the lower created forms are already found in the record of creation in Genesis 1 to 3 .

These themes recur in the covenant legislation. There, the ethical imperative rests on the indicative of redemption, which indicates how the vertical relationship with God dominates the horizontal relationship. The introduction to the covenant document of Exodus reminds Israel that they are a kingdom of priests for Yahweh (Ex. 19:5,6), and the preamble to the Decalogue reminds them that God the Lawgiver is first of all God the Saviour. The overview of Israel's history recorded in Deuteronomy $1-4$ precedes the Decalogue in Deuteronomy 5 and all the "legislative parts" following it. Chapters 32-34 of Exodus remind the people that redemptive grace has the necessary concomitant of forgiving grace, which provides even deeper motivation for obedience in our relations with other people(s). "Ethics then becomes a matter of gratitude, not of blind obedience alone" (Wright, 1983:21). Understanding this would contribute a lot towards a less legalistic and a more joyful ethic among African Christians.

\subsection{The God-centred history of biblical ethics}

The God-centred history of biblical ethics goes hand in hand with its basis in the covenant (Kaiser, 1983:33). Yahweh first and foremost revealed himself to Israel in his redemptive deeds in history. Evidently no man-made ethical code, whether European or African, could have this God-centred origin or history. This origin is the covenant of grace, both in its Old Testament and New Testament dispensations, and the historical, redemptive acts of God (Haselbarth, 1976:25). The ethics of natural man has no real motivation with regard to God. "It is not done", is the African motivation for ethics. This idea is often transferred to and implanted into the church, and the Christian life of the church is undermined and emaciated by this ahistoric, "originless" approach, without any motivation in God or his Son.

\subsection{The God-centred content of Old Testament ethics}

The God-centred content of Old Testament ethics refers in the first place to the character of God himself (Wright, 1983:26; Kaiser, 1983:29). Since Yahweh is a God of love and mercy, Israelites have to demonstrate the mercy shown to them in their dealings with people. They were strangers and slaves freed from Egypt by Yahweh, and therefore they are expected to behave in a humane manner towards strangers and slaves: "Do not oppress an alien; you yourselves know how it feels to be aliens, because you were aliens in Egypt" (Ex. 23:9; see also Deut. 15:12, 13, 15). 
This whole principle is summed up in one sentence in Leviticus 19:2: "Be holy because I, the LORD your God, am holy". But the rest of Leviticus 19 shows us that the kind of holiness which reflects God's own holiness is thoroughly practical [and therefore ethical - JAvR]. This principle of practical, ethical conduct includes generosity to the poor at harvest time, justice for workers, integrity in judicial processes, considerate behaviour to other people, equality before the law for immigrants, honest trading and other very "earthly" social matters. And in the ensuing chapters the refrain is heard: 'I am the LORD', as if to say, 'This is what I require of you because it is what I myself would do'. "This condition makes the command of Leviticus 19:2 quite breathtaking. Your quality of life, it said to Israel, must reflect the very heart of God's character" (Wright, 1983:27; Dyrness, 1979:172).

The broad Scriptural basis of this God-centred content of ethics reflects the fact that man was created in the image of God. One of the implications of this truth is that there is and should be a certain kind of analogy between God and man. God has the heart of a father, he is righteous, just, loving, compassionate and generous. He is not an idle God, he works. In this respect, man, his image, child and covenant partner, should reflect the character of his God. In the New Testament, in the light of our redemption through the death of Jesus Christ, the demand is focused on becoming Christ-like people. The summary of the fruits of the Spirit in Galathians 5:22-23 represents in fact the character traits of Jesus our Redeemer, and the description in 1 Corinthians 13 of what love is, is a description of Christ Himself.

This dimension opens the view to the vast chasm between African or traditional, pagan European ethics on the one hand and biblical ethics on the other, and also indicates the reason why Scriptural ethics has such a great transforming power in the lives of men and peoples. Scriptural ethics has transforming power because it has its origin, motivation and model in the love and redemptive work of God himself, which is brought home to the hearts of God's renewed people by the Spirit of God.

\subsection{God-centred motivation}

As for God-centred motivation, Israel is often warned against forgetting God's great redemptive deeds, lest they become heartless towards others in need. "If Israel were to lose sight of what God had done for them, it would inevitably lead to failure to obey his law. They would lose both the model and the motive" (Wright, 1983:29).

Obviously there can be no God-centred motivation for ethics among people who do not partake of God's redemptive love, again irrespective of whether these 
people are European, Semitic, ancient Egyptian or African - or even nominally Christian!

\subsection{God-centred responsibility}

To these four dimensions mentioned by Wright we may add that of God-centred responsibility. In this respect the relationship between individual and collective responsibility is important.

In all "primitive" communities the idea of collective consciousness and responsibility is basic (Krige \& Krige, 1954:75-81). The sense of interdependence is stronger in primitive communities than that of individual existence, and that of corporate responsibility supercedes that of individualism. "Primitive" Israel was no exception to this rule, but it was not limited to the early stages of the history of Israel. The concept of interdependence and corporate responsibility remained valid until New Testament times. Adam's whole posterity is included in his guilt, just as in the New Testament everyone who believes in Christ, shares in his righteousness. The family of Achan (Joshua 7), the children of the Canaanites (Joshua 6:24f.) and of the Amalekites (1 Sam. 15:3), and the descendants of Saul (2 Sam. 21), share in the guilt of their fathers. This communal element is typical of nomadic societies (Van Oyen, 1967:160), and God incorporated it into his covenantal relations with Israel.

Africans have, by virtue of their traditional ethical principles, more empathy for this corporative element in the Old Testament than Europeans have for it. It was striking that, when a group of Europeans was asked by a colleague of mine to report what revelation of God they found in Genesis 3, they referred to the nature of $\sin$, such as disobedience, rebellion, ingratitude. When the same assignment was given to a group of Africans, the response was almost unanimous: "One's sin does not affect only oneself, but also one's posterity."

On the other hand, although the communal element is very prominent in Israel's ethics and responsibility, this does not displace but merely supplements personal responsibility before God. The first man to transgress, Adam, is personally called to account: "Where are you? Who told you that you are naked? Did you eat of the forbidden fruit?" (Genesis 3). In the same way Cain is addressed and called to account (Genesis 4). At a very early stage believers are put before individual decisions: Abraham, for instance, in the call to Canaan (Genesis 12) and in the command to sacrifice his son (Genesis 22). The Decalogue, as well as the basic covenantal instructions of Deuteronomy 6 , is framed in the second person singular. It can be accepted that this sense of personal responsibility grew stronger in the course of the history of revelation, until Ezekiel's classical expression of it in Ezekiel 18: "The son will not die for the guilt of the father, neither will the father die for the guilt of the son". 
In this respect there are some similarities between Old Testament and traditional African ethics. When missionaries first made contact with Africans, the tendency among Africans was still towards a communal response to the gospel. In modern times, however, this has drastically changed, almost to the other extreme. Even more than in European households, one often finds religious and denominational divisions in African households, because of the tendency to regard religious decisions as exclusively the responsibility of the individual.

\subsection{God-centred expectation}

A sixth dimension of Scriptural ethics is its God-centred expectation. In the framework of the covenant, promises are the reverse side of the sanctions. In both Leviticus 26 and Deuteronomy 28 the promises and blessings precede the threats and curses. This concept of final judgment became more prominent as redemptive history advanced, and is drawn in clear terms in the New Testament, but it starts in Genesis 3: "Where are you?" The very same principle is revealed in the parables of our Lord, for instance the parable of the sheep and the goats (Matt. 25:31-46).

\subsection{God-centred universality}

A seventh dimension of biblical ethics is its God-centred universality. Kaiser $(1983: 11,12)$ mentions the example of the heathen cities, Sodom and Gomorrah, whose sins were so grievous that the outcry rose to God in heaven, although they did not partake of God's particular revelation through his word. Their sins are judged as being just as serious as those of Gibeah (Judg. 19, 20). But even more striking is the indictment of the nations by the prophet Amos in the sermon recorded in the first two chapters of his prophecies. Damascus, Gaza, Tyre, Edom, Ammon and Moab are called to account and judgment is passed on them in exactly the same way as on Israel and Judah. And the accusation is in every case not the obvious one of idolatry, but rather transgressing the universal norm of God the Creator, who demands that people treat other people with mercy and respect. If people like the warring factions of the Zulu in Natal could understand this, and if the church of Christ can illustrate this in its conduct in the midst of these conflicts, it should contribute a lot towards mutual acceptance among individuals of different groups. In this respect one could only hope that the church among the Zulu people would do better than the church among Afrikaners in the apartheid era.

\subsection{Biblical ethics is distinguished by its God-centred internal character}

In the eighth place, biblical ethics is distinguished by its God-centred internal character. God judges not only the outward deeds, but even more the intent and 
motive of the heart. The tenth commandment of the Decalogue is unique in this respect when compared to pagan religious statements. That the tenth commandment refers to one's inner attitude and forbids "sins of the mind", has been contested by some scholars, such as Albrecht Alt. Kaiser (1983:235-239) who convincingly argues the case for the tenth commandment referring to sins of intention. Keil and Delitzsch (1869:124) on Exodus 20:17 write, "The last or tenth commandment is directed against desiring (coveting), as the root from which every sin against a neighbour springs". This view is shared by commentators such as Alan Cole (1973:161). Dyrness points out that the final command against coveting is also the most inclusive and the most difficult to enforce. But this is yet another example of how well Scripture understands the motivational aspect of sin. Sin is a matter of the heart before it is a matter of behaviour. Coveting was the basic sin of Adam. It is not insignificant that this is the last of the commandments, for it virtually calls out for its New Testament interpretation which Christ supplies (Matt. 5:21-28; Dymess, 1979:180).

In the same way, sacrifices are of no avail if there is no broken spirit and contrite heart over our sins (Ps. 51:17; see also Kaiser, 1983:7). It would be wrong to suppose that Israel did not know sins of thought. Why, then, would Job have made a covenant with his eyes not to look lustfully at a woman (Job 31:1)?

In African ethics, intent and motivation are taken into account in evaluating a person's conduct, but for a different reason, to wit the fact that brooding anger and jealousy can actually activate black magic and kill the object of hatred. It is a form of witchcraft (see also Bujo, 1992:37; Bujo, 1990:98-99). There is no theocratic dimension to it, the motivation is the possible threat to interpersonal relations.

\subsection{God-given property}

The basic assumption of the whole of Scripture is that everything belongs to God, the Creator. "The earth is the LORD's, and everything in it," we read in Psalm 24:1. But in his grace, God grants to his people property to possess for themselves, although it remains God's property (Lev. 25:23). In this granting, the individual element is predominant. When the Israelite brings the first fruits to the temple, he is instructed to recite the words: "He brought us to this place and gave us this land, a land flowing with milk and honey; and now I bring the firstfruits of the soil that you, O LORD, have given me" (Deut. 26:9,10). One should observe the singular form $m e$ here.

The Israelite did not think in terms of the whole land given to the whole nation. That concept could have been compatible with the whole land being held on the nation's behalf, as it were, by a king as their representative. That, in fact, was the Canaanite system (Wright, 1983:54). 
The history of Ahab and Naboth, recorded in 1 Kings 21, illustrates how strongly this unalienable right of possession was experienced among Israelites. Micah expresses the horror of faithful Yahwists at the disregarding of covenant law by the nobles of Judah in the times of Jotham and Ahaz: "They covet fields and seize them. They defraud a man of his home, a fellow-man of his inheritance" (Mic. 2:2). David does not dare to confiscate Araunah's piece of land, but buys it (2 Sam. 24:24).

According to traditional African custom, individual property was limited to livestock and moving possessions, but the land was always, and even unto this day predominantly is, communal property. The advantage of the Israelite system found in the Old Testament and sanctioned by God himself, was that people tend to care for the land they own, but to exploit and ravage communal land, since it is not in the first instance the individual who benefits from conservation farming, but the whole of the community, who might not be as conservation conscious as the individual and therefore do not do their share in it. Furthermore, if a field is not one's property, it can and indeed often is taken away by a jealous chief for himself or given to one of his favourites, especially after one has developed it.

\subsection{God-given jurisprudence}

In the case of natural man - and that includes black natural man just as surely as white natural man - the natural tendency is to limit loyalty and justice to the ingroup, those towards whom one would be naturally inclined to feel love. The ethical code of Africans demands that in traditional court cases, for the sake of safeguarding the integrity of the tribe, powerful persons often win their cases, because they can do more harm to the tribe if they are dissatisfied with the result of litigation (Van Warmelo \& Phophi, 1948:11-15). In the covenant legislation, however, "even the rights of the lowliest foreigner are placed under the protection of God; and if he is also dependent, without full legal rights, to oppress him is like oppressing the widow and the orphan, a transgression worthy of punishment, which calls forth God's avenging retribution" (Eichrodt, 1967:321). The basic principle applied here is that judgement belongs to God (Deut. 1:17), and therefore favouritism is forbidden (Deist, 1986:181).

The principle of compensation and reconciliation, which is sadly neglected in European jurisprudence, is the main object of African penal procedure. In this respect, African law is much nearer to that of Scripture than European law. On the other hand, the theistic angle which is brought to the fore by the principle of purging is absent in Africa, except in cases of murder and witchcraft, where the culprits are eliminated because they constitute a threat to society. 


\subsection{God-given daily task: the work ethic}

In Africa, with its magico-animistic beliefs, there often exists no evident relationship between input in the form of work and results in the form of prosperity and blessing. Blessing, good luck, and prosperity are often regarded rather as the results of magic powers. The result is that there is little appreciation for the "Puritan work ethic" which lies at the basis of the prosperity of Western civilization. According to the African work ethic work is a kind of necessary evil, which no one will indulge in unless compelled to by circumstances. According to a Western work ethic work includes studying diligently at school and university level. The dissatisfaction of many African students and the constant strikes are partly a result of these basic magico-animistic beliefs. Why should some students fail, while others pass? There is a strong suspicion that lecturers fail students because they simply do not want them to have the benefits of a degree or diploma. Why not grant it to everyone, so that everyone may get work? Whether those graduates are technically qualified for any work is beside the point. It is the duty of the government to provide work for those who can show a qualification on paper, so that they might draw a salary. Again, the question whether the work is useful is not important. People simply demand a slice of the cake, which they regard as their due, because they have obtained a diploma or degree. Many instances of this attitude can be adduced. The problem is not that Africans are lazy by nature, but that the magical substratum in the world view tends to discourage diligence.

Needless to say, this work ethic can only lead to economic disaster, poverty and hunger, and I believe that it is indeed one of the most important reasons for Africa's dismal economic situation.

I also believe that Scripture, in the much-maligned Puritan work ethic, provides the answer to this dismal predicament of Africa. Creative work, ruling and developing the earth in a responsible way, is one of the very first and basic commands of God to man (Gen. 1:28). Nature and the results of work have, to be sure, been influenced by the fall (Gen. 3:17-19), but work is definitely not the result of the fall. The command to work was given with creation, not with the fall. Therefore diligent work is just as much required from Christians than from pagan slaves ( 2 Thes. 3:6-10).

\subsection{Christ, the Spirit and the New Creature}

The distinctive elements of New Testament ethics are Christ-centred. In the redemptive acts of the Lord Jesus, Christian ethics receives additional motivation. Because Christ loved us even while we were still God's enemies, we should and can also love our enemies. The Holy Spirit, the Spirit of the risen Christ, regenerates us and enables us to be conformed to the image of Christ, our 
Redeemer and King. Our conduct and motives therefore are totally controlled by the love of Christ.

The Holy Spirit not only regenerates us, but also dwells in us. This brings further motivation for sexual purity and respect for our bodies and those of others. In Africa, sexual instruction consists of nothing else than "dont's". This kind of unmotivated instruction is futile in a modern, unprotective society. The new motivation of respect for the human body, the temple of the Spirit (1 Cor. 6:19), alone can provide a sound basis for sexual purity. Equally powerful for marriage morality is the principle that human marriage should reflect the relationship of Christ and his church: holy, based on Christ's love, permanent and exclusive (Ef. 5:22-33).

\section{Conclusion}

There are many similarities between Scriptural ethical principles and those of Africa, such as the importance of the community, but these similarities should not blind us to the radical differences, based on the theocentric character of Old Testament ethics, which is entirely absent in Africa.

Biblical ethical principles, resting on the personal knowledge of, love for and gratitude towards a personal God, have a renewing effect on people and society as a whole, especially in times of spiritual renewal, when God becomes particulary real to people. Traditional African ethics cannot renew society. According to African ethics, the idea of nepotism, "providing for one's family", "looking after one's own people", is a virtue. Corruption has become a way of life in many African countries where biblical ethics has not yet penetrated, as the disclosures in the media (November/December 1993) of corruption in the administration of Lebowa and Gazankulu illustrate.

\section{Bibliography}

BUJO, Bénézet. 1990. African Christian morality at the age of inculturation. Nairobi : St. Paul Publications - Africa.

BUJO, Bénézet. 1992. African theology in its social context. New York : Orbis Books.

COLE, A. 1973. Exodus. An introduction and commentary. London : IVP.

DAVIDSON, J. 1950. The doctrine of God in the life of Ngombe, Belgium Congo. (In Smith, E.W. ed. African ideas of God. London : Edinburgh House Press. p. 163-179.)

DE GROOT, J. \& HULST, A.R. 1952. Macht en wil. De verkondiging van het Oude Testament aangaande God. Nijkerk : Callenbach.

DYMOND, G.W. 1950. The idea of God in Ovamboland, South West Africa. (In Smith, E.W., ed. African ideas of God. London : Edinburgh House Press. p. 135-155.)

DYRNESS, W. 1979. Themes in Old Testament theology. Exeter : Paternoster Press. 
EICHRODT, W. 1967. Theology of the Old Testament, Vol. II. London : SCM Press.

GUILLEBAUD, R. 1950. The doctrine of God in Ruanda-Urundi. (In Smith, E.W., ed. African ideas of God. London : Edinburgh House Press. p. 180-200.)

HASELBARTH, Hans. 1976. Christian ethics in the African context. Ibadan : Daystar Press.

ILOGU, Edmund. 1974. Christianity and Ibo culture. Leiden : Brill.

KAISER, W.C. Jr. 1983. Toward Old Testament ethics. Grand Rapids : Academic Books.

KEIL, C.F. \& DELITZSCH, F. 1869. Biblical comentary on the Old Testament. Volume 2. Edinburgh : T. \& T. Clarke.

KRIGE, E.J. \& J.D. 1954. The Lovedu of the Transvaal. (In Forde, D, ed. African worlds. London : OUP. p. 54-82.)

MBITI, J.S. 1970. Concepts of God in Africa. London : SPCK.

MBITI, J.S. 1975. The prayers of African religion. London : SPCK

McVEIGH, M.J. 1974. God in Africa. Conceptions of God in African traditional religion and Christianity. Cape Cod : Claude Stark.

METUH, E.I. 1981. God and man in African religion. London : Geoffrey Chapman.

RADER, D.A. 1991. Christian ethics in an African context. Focus on urban Zambia. New York : Peter Lang.

SETILOANE, G.M. 1976. The image of God among the Sotho-Tswana. Rotterdam Balkema.

SMITH, E.W. ed. 1950. African ideas of God. London : Edinburgh House Press.

SNAITH, M.H. 1944. The distinctive ideas of the Old Testament. London : Epworth Press.

VAN OYEN, H. 1967. Ethik des Alten Testaments. Gütersloh : Gerd Mohn.

VAN WARMELO, N.J. \& PHOPHI, W.M.D. 1948 . Venda Law, Part I. Ethnological Publications, No. 23. Pretoria : Government Printer.

VRIEZEN, Th.C. 1974. Hoofdlijnen der theologie van het Oude Testament. Wageningen : H. Veenman en Zonen.

WRIGHT, C.J.H. 1983. Living as the People of God. The relevance of Old Testament ethics. Leicester : Inter-Varsity Press. 